https://doi.org/10.5817/NR2019-1-10

\title{
Ruská a mezinárodní pocta prof. Danuši Kšicové
}

СТУКАЛОВА, О., ОЛЕСИНА, Е. (ред.): Интеграция и образование. Теория и практика междисииплинарных исследований. Посвящается памяти выдающегося слависта Дануше Кшицовой. Москва: Федеральное государственное бюджетное научное учреждение «Институт художественного образования и культурологии Российской академии образования», 2017. ISBN 978-5-905451-29-4.

Editorky doprovodily tento svazek krátkou předmluvou, v níž píšou o prof. Danuši Kšicové (1932-2017), které je tato publikace věnována. Její název celkem přesně odpovídá zaměření zvěčnělé brněnské slavistky, která v českém prostředí založila pobočku mezinárodní asociace Word and Image Studies. Celý život se věnovala nejen literatuře, ale zejména vztahům různých druhů umění, zejména výtvarného, hudebního a literárního. Zkoumala povahu literárních žánrů, zvláště básnických (poéma) a také cestopisů v diachronní a srovnávací dimenzi česko-ruské. Kromě rusistiky se zabývala i dalšími slovanskými literaturami, kromě české např. ukrajinské. Byla koeditorkou pamětí jedné rodiny volyňských Čechů; její druhý manžel Evžen Petrov (1941-1999) byl s touto problematikou rodinnou anamnézou prímo spojen.

Rozsáhlý svazek (celkem 494 stran) je uveden několika studiemi, z nichž klíčové místo zaujímá rozhovor její brněnské kolegyně, která do Brna přišla roku 1994 z Ševčenkovy kyjevské univerzity, Halyny Myrono(vo)vé pod názvem Ja ješče zdes'... $Z$ díla D. Kšicové je tu studie (fragment z její knihy) o cestopisech 16. století. Na to volně tematicky navazuje komentovaná recenze Mar’jany Levické právě o knize D. Kšicové Cesty do Svaté země (2013). Larisa Aleksejevová píše o dnešním informačním prostoru, Jelena Kabkovová a Olga Stukalovová o pedagogice umění.

Oddíl o interdisciplinaritě v humanitních vědách uvádí Attila Hollosh, jenž analyzuje životní dráhu Lászla Csopeje; nestor ruské literární teorie Jurij Mann poukazuje na Gogolovu Ženitbu jako na sbližení s modernou, Zsuzsana Kalafaticsová demonstruje význam rukopisu v litografické knize Lászla Borisa (Gogolovy Bláznovy zápisky), autor této recenze popisuje roli Josefa Jiráska jako první část triptychu o česko-ruských literárních vztazích, Ágnes Dukkonová líčí recepci díla Dostojevského v Madarsku v první polovině 2o. století, Josef Dohnal vidí Dostojevského Zápisky z podzemí jako hodnotově orientovaný polylog, Zinaida Kravčenková se zabývá barevnou paletou u Dostojevského, Jelena Maklakovová a Matvej Čertovskich píšou o vydavatelské a novinářské práci N. Někrasova, Olesja Juduškinová analyzuje úlohu žánru gazelu (ghazal) v ruské poezii stř́brného věku, o rituálu, gnósi a hermeneutice $\mathrm{v}$ díle V. Nabokova Pozvání na popravu pojednává Zoltán Józsa, Jekaterina Akišinová ukazuje na sémantický př́stup $\mathrm{k}$ hudební kultuře. $\mathrm{Z}$ dalších uvádíme alespoň 
studii J.S. Medkové o tvaru sochy a mýtu, M. Lazareva o mystickém obrazu světa a A. Poleuchina o integraci deviantních skupin.

Oddíl o pedagogických aspektech interdisciplinarity uvádějí Ljubov' Savenkovová a Jelena Olesinová. $Z$ desítek studií vybíráme např. práci Svetlany Petrovové o multimediálním vzdělávacím prostředí, Tat̉jany Nadolinské o psychotechnické škole K. Stanislavského, Olggy Davydovové o vizualizaci znaku, Mariji Rozanovové o integraci výtvarného umění a literatury. Jednotlivé studie se zabývají i konkrétními didaktickými a metodickými problémy výuky uměnovědných oborů a předmětů a reflektují poměrně složité prostředí postmoderní doby.

Př́tomný svazek ukázal na důležitý aspekt činnosti zesnulé brněnské badatelky, a to spojení interdisciplinarity se zkoumáním metodické aplikace, tedy, jinak řečeno, základního a aplikovaného výzkumu. Tento proud bádání $\mathrm{D}$. Kšicová skutečně představovala, a to již analýzami spojitostí mezi různými druhy umění, které prováděla systematicky, a přesahy od literární vědy $k$ estetice, uměnovědám a jejich metodické transcendenci. Zde se se její úsilí protalo se zaměřením moskevského pracoviště, jež tento svazek vydalo, ale i s dalšími rusisty, z nichž jsou zastoupeni badatelé čeští a madarští.

Problémem svazku je jeho rozsáhlost, a tudíž někdy nepřehlednost a tematická a metodologická heterogenita: na druhé straně tyto vlastnosti mohou být někdy výhodou jako široká názorová paleta, kdy se přirozeně posiluje všeobecně informativní funkce. Velmi užitečný by tu byl jmenný i věcný rejstř́ik, možná i celkový seznam použité literatury, který by obepnul problematiku vydavatelského pracoviště, citelná je absence přepisů jmen neruských přispěvatelů do latinky. Snad by se tu v závěru hodila i nějaká sumarizující, scelující a hodnoticí stat. Pozitivní je sepětí teorie a praxe, názornost, uvádění pedagogických postupů a her. A také - last but not least - výborný fotografický průvodce životem Danuše Kšicové.

Problémem zůstává spíše budoucnost tohoto bádání, jeho výhledy metodologické, metodické a také generační: rozhodně je to směr bádání, který je mimořádně náročný na rozhled, talent, hlubinné založení, znalost řady jazyků aktivně i pasivně, citlivost $\mathrm{k}$ různým druhům umění, estetickou empatii, ale je to bádání perspektivní, rozšiřuje půdorys komplexního vědeckého výzkumu umění jako takového, zasahuje i do obecných otázek estetiky a konkretizuje rozpětí tzv. areálových studií.

Ivo Pospíšil

\section{Bibliografie:}

STUKALOVA, O., OLESINA, Je. (red.) (2017): Integracija i obrazovanije. Teorija i praktika meždisciplinarnych issledovanij. Posvjaščajetsja pamjati vydajuščegosja slavista Danuše Kšicovoj. Moskva. 